\title{
Factors Related to Earthquake Disaster Preparedness Among Teachers at Elementary Schools in the Coastal Area of Padang Barat Subdistrict 2018
}

\author{
Nopriadi $^{1, *}$, Dinia Hafizah ${ }^{2}$, Nizwardi Azkha ${ }^{2}$, Emy Leonita $^{3}$ \\ ${ }^{1}$ Nursing Faculty, Riau University, Pekanbaru, Indonesia \\ ${ }^{2}$ Public Health Faculty, Andalas University, Padang, Indonesia \\ ${ }^{3}$ Hang Tuah Public Health Science of Pekanbaru, Pekanbaru, Indonesia \\ *Corresponding author. Email: nopriadi_dhs@yahoo.com
}

\begin{abstract}
Preparedness of teacher in elementary school is important to determine the level of student's knowledge about preparedness through learning process in school. This study was purposed to determine related factors to earthquake disaster preparedness among teachers at elementary schools in The Coastal Area of Padang Barat Sub-district 2018. This study was conducted at elementary schools in The Coastal Area of Padang Barat Subdistrict using cross sectional design. There are 48 teachers as samples selected by Proportional Random Sampling method. Data collection is done with interview using questionnaire. Data were analyzed using univariate and bivariate analysis with Chi-Square test. The findings based on univariate analysis have revealed that less than half of the respondents are not ready to face earthquake of $47.9 \%$. The findings based on bivariate analysis showed that knowledge $(p=0.019)$ and behavior $(p=0.022)$ were related to preparedness, meanwhile experience $(p=0.086)$ and year of works $(p=0.343)$ have no relationship with preparedness. Knowledge and behavior are related into the preparedness of teachers in the coastal areas of Padang Barat sub-district, meanwhile experience and year of works are not related into the disaster preparedness of teachers in the coastal areas of Padang Barat sub-district 2018. Training programs of preparedness should be continuously implemented for train the teachers to actively deal with disaster preparedness.
\end{abstract}

Keywords: preparedness, teacher of elementary school, earthquake

\section{INTRODUCTION}

Indonesia is a country with high disaster risk in earthquakes, tsunami, volcanic eruptions, and other geologic disasters. Rows of volcanoes in Indonesia are form part of rows of mountains and volcanoes which spread across the island of Asia-Pacific which called by Ring of Fire or circum-Pacific. Zones and areas are located in between the tectonic plates and rows known as 'active zone' or 'fore arc' with high tectonic activity which frequently results in earthquakes [1][2].

The west area of Sumatera is forming the margin of world's plate and arc with high tectonic activity. Discovered by several earthquakes in this area which caused by the composed of fragments of Indo-Australian and Eurasian tectonic plates. Furthermore, earthquakes in West Sumatera are not only caused by the fragments of tectonic plates but the existences of Mentawai Fault and Sumatera Fault [3].

Based on its geographical position, Padang is located in the westside of Sumatera's islands. This consideration put Padang is amongst earthquakes disaster-prone area, especially earthquakes caused by submarine earthquake (tectonic earthquake) [4]. Based on data from Padang Regional Disaster Management Agencies, the September 30th 2009 earthquake have caused the greatest number of people. There were 383 number of deaths, 431 people suffered of major injury, and 771 people of the minor ones. The most deaths were happened in Padang Barat sub-district with the death toll reached 81 people.

In order to face of such risk, disaster preparedness can be held to prepare the community in dealing with disaster, especially earthquakes, to reduce number of victims in high-risk areas. Students in elementary are part of vulnerable group. While the disaster happen, the role of teachers are needed to provides any social protection and safety feelings. Preparedness of teachers are really important to determine the knowledge of disaster preparedness of student in learning process at school, in theoretical and practical [5][6].

Based on that views, researcher has interest to do research on influencing factors on earthquake disaster preparedness of the teachers at elementary school in the coastal areas of Padang Barat sub-district 2018. 


\section{METHOD}

This research in quantitative research with cross sectional study design. This research is conducted in coastal areas of Padang Barat sub-district. The population which used in this study is 80 teachers from 8 elementary schools in coastal areas of Padang Barat sub-district which included into the red zonation (high risk alert) $\leq 500$ meters lengths from the coastlines. As samples, there are 48 teachers who selected by Proportional Random Sampling from the chosen elementary schools.
This research is collected data in primary data and secondary data forms. Data process started by data editing, coding, data entry and data cleaning. Data were analyzed with univariate and bivariate analysis with Chi-Square test.

\section{RESULTS AND DISCUSSION}

A Distributions and Frequencies of Dependent and Independent Variables of Teachers in Coastal Areas of Padang Barat Sub-district.

Table 1. Distributions and Frequencies of Dependent and Independents Variables of Teachers Related with Disaster Preparedness in Coastal Areas of Padang Barat Sub-district 2018

\begin{tabular}{lcr}
\hline \multicolumn{1}{c}{ Variables } & Frequency (f) & Percentag \\
\hline Preparedness & & \\
a. Not ready & 23 & 47.9 \\
b. Ready & 25 & 52.1 \\
Total & 100 & 100,0
\end{tabular}

\section{Knowledge}

$\begin{array}{lcc}\text { a. Low } & 16 & 33.3 \\ \text { b. High } & 32 & 66.7 \\ \text { Total } & 100 & 100,0\end{array}$

Behavior

$\begin{array}{lcc}\text { a. Negative } & 20 & 41.7 \\ \text { b. Positive } & & \\ \text { Jumlah } & 28 & 58.3 \\ & 100 & 100,0\end{array}$

\section{Experience}

$\begin{array}{lcc}\text { a. Low } & 18 & 37.5 \\ \text { Experience } & 30 & 62.5 \\ \text { b. High } & & 100,0 \\ \text { Experience } & 100 & \end{array}$

\section{Year of Works}

$\begin{array}{lcc}\text { a. New } & 19 & 39.6 \\ \text { b. Old } & & 60.4 \\ \text { Total } & 29 & 100,0 \\ & 100 & 100\end{array}$

Based on the table 1 , there are $47.9 \%$ teachers are not ready to anticipate the earthquake, $33.3 \%$ have not a proper knowledger about earthquake, $41.7 \%$ have a negative behavior to face the earthquake, less than
$37.5 \%$ have no experience in earthquake, and $39.6 \%$ just started their works as teacher.

B. The Correlation of Independent and Dependent Variables of Teacher in Coastal Areas of Padang Barat Sub-district 
Table 2. The Correlation of Independent and Dependent Variables of Teachers Related with Disaster Preparedness in Coastal Areas of Padang Barat Sub-district 2018

\begin{tabular}{|c|c|c|c|c|c|c|c|}
\hline \multirow[t]{3}{*}{$\begin{array}{l}\text { Independent } \\
\text { Variables }\end{array}$} & \multicolumn{4}{|c|}{ Preparedness } & \multirow{2}{*}{\multicolumn{2}{|c|}{ Total }} & \multirow{3}{*}{$\begin{array}{c}p- \\
\text { value }\end{array}$} \\
\hline & \multicolumn{2}{|c|}{$\begin{array}{l}\text { Not } \\
\text { Good }\end{array}$} & \multicolumn{2}{|c|}{ Good } & & & \\
\hline & f & $\%$ & f & $\%$ & f & $\%$ & \\
\hline \multicolumn{8}{|l|}{ Knowlege } \\
\hline Low & $\begin{array}{l}1 \\
2\end{array}$ & $\begin{array}{c}75 . \\
0\end{array}$ & 4 & $\begin{array}{c}25 . \\
0\end{array}$ & 16 & 100 & \multirow{3}{*}{0,019} \\
\hline Hight & $\begin{array}{l}1 \\
1\end{array}$ & $\begin{array}{c}34 . \\
4\end{array}$ & $\begin{array}{l}2 \\
1\end{array}$ & $\begin{array}{c}65 . \\
6\end{array}$ & 32 & 100 & \\
\hline Total & $\begin{array}{l}2 \\
3\end{array}$ & $\begin{array}{c}47 . \\
9\end{array}$ & $\begin{array}{l}2 \\
5\end{array}$ & $\begin{array}{c}52 . \\
1\end{array}$ & 48 & 100 & \\
\hline \multicolumn{8}{|l|}{ behavior } \\
\hline Negative & $\begin{array}{l}1 \\
4\end{array}$ & $\begin{array}{c}70 . \\
0\end{array}$ & 6 & $\begin{array}{c}30 . \\
0\end{array}$ & 20 & 100 & \multirow{3}{*}{0,022} \\
\hline Positive & 9 & $\begin{array}{c}32 . \\
1\end{array}$ & $\begin{array}{l}1 \\
9\end{array}$ & $\begin{array}{c}67 . \\
9\end{array}$ & 28 & 100 & \\
\hline Total & $\begin{array}{l}2 \\
3\end{array}$ & $\begin{array}{c}47 . \\
9\end{array}$ & $\begin{array}{l}2 \\
5\end{array}$ & $\begin{array}{c}52 . \\
1\end{array}$ & 48 & 100 & \\
\hline \multicolumn{8}{|l|}{ Experience } \\
\hline Low Experience & $\begin{array}{l}1 \\
2\end{array}$ & $\begin{array}{c}66 . \\
7\end{array}$ & 6 & $\begin{array}{c}33 . \\
3\end{array}$ & 18 & 100 & \multirow{3}{*}{0,086} \\
\hline High Experience & $\begin{array}{l}1 \\
1\end{array}$ & $\begin{array}{c}36 . \\
7\end{array}$ & $\begin{array}{l}1 \\
9\end{array}$ & $\begin{array}{c}63 . \\
3\end{array}$ & 30 & 100 & \\
\hline Total & $\begin{array}{l}2 \\
3\end{array}$ & $\begin{array}{c}47 . \\
9\end{array}$ & $\begin{array}{l}2 \\
5\end{array}$ & $\begin{array}{c}52 . \\
1\end{array}$ & 48 & 100 & \\
\hline \multicolumn{8}{|l|}{ Year of Works } \\
\hline New & 7 & $\begin{array}{c}36 . \\
9\end{array}$ & $\begin{array}{l}1 \\
2\end{array}$ & $\begin{array}{c}63 . \\
1\end{array}$ & 19 & $\begin{array}{c}100 . \\
0\end{array}$ & 0,343 \\
\hline Old & $\begin{array}{l}1 \\
6\end{array}$ & $\begin{array}{c}55 . \\
1\end{array}$ & $\begin{array}{l}1 \\
3\end{array}$ & $\begin{array}{c}44 . \\
9\end{array}$ & 29 & $\begin{array}{c}100 . \\
0\end{array}$ & \\
\hline Total & $\begin{array}{l}2 \\
3\end{array}$ & $\begin{array}{c}47 . \\
9\end{array}$ & $\begin{array}{l}2 \\
5\end{array}$ & $\begin{array}{c}52 . \\
1\end{array}$ & 48 & $\begin{array}{c}100 . \\
0\end{array}$ & \\
\hline
\end{tabular}

Based on the table 2, there are correlations between knowledge and preparedness of teachers in coastal areas $(p$-value $=0.019)$, behavior with preparedness of teachers in coastal areas $(p$-value $=0.022)$, and no relation between experience $(p$-value $=0.086)$ and year of works $(p$ value $=0.343$ ) with preparedness of teachers in coastal areas.

The research have revelead that less than half of the respondents which is $47.9 \%$ respondents are not ready to face the earthquake disaster. Preparedness of the unready respondents caused by respondents are not prepare the material things such as nailing/lacing the bookshelves into the wall or floor. In addition, some respondents are never give the preparedness education because no standards in curriculum about disaster, especially for the earthquake. Meanwhile, some of respondents are not understand about signs/warnings if disaster happen in school.

Schools need to anticipate any material by nailing/lacing the bookshelves into the wall or floor to make it safe. Schools also need to put disaster education into the learning process to increase the preparedness of teachers and knowledge of students about disaster. 
Based on the research, $33.7 \%$ respondents have unproper knowledge about disaster. In this category, almost all of the respondents have a very low knowlegde about preparedness, unallowed things to do in buildings when earthquake happens, and symptoms of a big earthquake. Schools are need to do more anticipating program to increase the knowledge of diasater by doing education and training about disaster, especially earthquake by the association or organization related such as Regional Disaster Management Agencies, Preparedness of Tsunami Committee, and others. In addition, material education of preparedness in school are needed in order to increase the understanding of teachers about how to face the earthquake with big intensity by some organized steps and directions.

Based on the research, $41.7 \%$ respondents have a negative behavior. In this category of behavior, especially for respondent who are not agree to prepare the anticipations of disaster. Beside that, respondents disagree to cover head when we go to the safer place when earthquake happens and also disagree for calming the students in classroom when earthquake happens.

Schools are needed to prepare the positive behavior or teacher in anticipating the earthquake. Anticipation can be done by add and follow the information of disaster from printed media or online to shape the concept of risk and danger of earthquake for teachers as their basic to implement preparedness in actions.

Based on the research, $37.5 \%$ respondents have no experience about facing earthaquake disaster. In this category, a few of respondents have no experience in facing earthquake in school, especially none of teachers ever struck down by debris in earthquake evacuation. Beside that, none of teachers ever trapped into a big intensity of earthquake or teaching in the classroom when the earthquake happens.

Experience can be developed by increasing the knowledge of teachers about effects or impacts of earthquake such as interactive learning process with videos or stories about victims of earthquake disaster.

Based on research, a few of respondents, which is $39.6 \%$ respondents just started their working experience. The year of works can affect the ability of analyzing the situation and condition in the workspace which also affected by awareness and knowledge. ang baru. This factor can be affected experiences of disaster. People with years of work in an institution will be filled by experiences.

The result of statistic review have showed that there is a significant relation correlation with $p$-value $<0.05(0.019)$ between number of knowledge with preparedness of teacher in anticipating the earthquake. This result are fit into the study from Harahap (2015) that preparedness of disaster can be affected by knowledge. Other study from Susilawati (2015) in Bantul showed that there are a correlation between knowledge and preparedness in facing the earthquake disaster[7,8].

Knowledge about disaster can be a reason why people do actions of disaster preparedness. Knowledge will affect the awareness of society to do disaster preparedness, especially when they live in disaster-prone areas[9]. If knowledge of disaster and preparedness of teacher are proper, it will be very impactful for effectiveness of actions for school disaster preparedness itself (as personal or as part of the school).

The teachers need to be more attractive to reach the knowledge about disaster which will affected their preparedness of disaster. Teachers also needs to be more active in improving the preparedness of school by increasing their knowledge of disaster as the role model for school and do sharing about their knowledge so it can be more helpful when earthquake happens.

The result of statistic review have showed that there is a significant relation with p-value $<0.05(0.022)$ between behavior with disaster preparedness of teacher in anticipating the earthquake. This research is fit into the research of Ahmad (2017) that there are a correlation between behavior with disaster preparedness. Furthermore, the research of Harahap (2015) showed that preparedness can be affected by the behavior of the society[7,10].

Behavior is one of the factors which affect the disaster preparedness because behavior is a tendency to do respond and actions which should be done in order to anticipating the disaster. Based on the statistic review, it showed that more positive the behaviour is, it will increase the preparedness level of individu.

The school needs to increase the positive behavior of earthquake preparedness. It can be done by doing socialization and coordination with related instution such as school, public health centre, Regional Disaster Management Agencies, and others.

The teachers can train their respond to disaster and do the real action of preparedness.

The result of statistic review have revealed that experience have no correlation with disaster preparedness with $p$ value $>0.05(0.086)$. The result of this research is not fit to the study of Havwina (2016) that experiences of earthquake with disaster preparedness. Research from Permana (2015) showed that there are a relation between experience and disaster preparedness[11,12].

This research conclude that experience of teachers of elementary school as respondents in facing the disaster have no relation with preparedness of the teachers. Experience of respondents in facing the disaster is not determine the level of preparedness. Experience in any individu are different, people with experience of facing the disaster may not have a proper respond of the upcoming disaster. But, the experience of disaster may be a learn and reflection of the ability of preparedness.

The result od statistic review have showed that there are no correlation between year of works with preparedness of teachers in facing the earthquake with $p$-value $>0.05$ (0.343). This result are not fit into the study of Wahidah (2017) that year of works have a correlation with disaster preparedness. Furthermore, the study of Fitriana (2017) also showed that there are a relation between year of works with disaster preparedness $[13,14]$.

This result can conclude that year of works from teachers of elementary school as respondents in facing the disaster 
have no relation with the level of preparedness of the teachers. People with more working experience cannot guarantee the level of preparedness they have. But, teachers who teach in earthquake-prone area must be aware and responsive to any signs of disaster and tracks of evacuation if the earthquake happens, with a long of short working experience.

\section{CONCLUSION}

Less than a half of teachers in the coastal areas of Padang Barat sub-district are not ready in preparedness of earthquake disaster. A few of teachers in the coastal areas of Padang Barat sub-district have unproper knowledge about earthquake disaster. Less than a half of of teachers in in the coastal areas of Padang Barat sub-district have a negative behavior in anticipating earthquake disaster. A few of teachers in the coastal areas of Padang Barat subdistrict have no experience in anticipating the earthquake disaster. A few of teachers in the coastal areas of Padang Barat sub-district just started their working experience as a teacher in their school.

Knowledge and behavior are related into the preparedness of teachers in the coastal areas of Padang Barat subdistrict, meanwhile experience and year of works are not related into the disaster preparedness of teachers in the coastal areas of Padang Barat sub-district 2018. Education and training programs of preparedness should be continuously implemented for train the teachers to actively dealing with disaster preparedness.

\section{REFERENCES}

[1] National Disaster Management Agency. Tough Agile Handbook for Disaster Response: BNPB; 2017.

[2] National Disaster Management Agency. Indonesian disaster Risk (RBI).Jakarta: BNPB; 2016.

[3] Triyono R. Review of the earthquake in West Sumatera 30 September 2009 as disaster mitigation efforts. 2015

[4] Central Statistic Agency of Padang. Padang City in numbers. Padang: BPS Padang City; 2018

[5] Governor of West Sumatera. Regional regulation of West Sumatra province No. 5Year 2007 on disaster management. West Sumatera: Governor of West Sumatera; 2007.

[6] Government of the Republic of Indonesia. Law No. 24 year 2007 on Disaster. Jakarta: Government of INDONESIA; 2007.

[7] Harahap ME, Lufri M, Muthalib A. Influence of knowledge and attitude to community preparedness in the face of flood disaster at Bukit Lawing Plantation Village Bahorok year 2011. IMELDA Nursing scientific journal. 2015; 1 (1): 22-31.

[8] Susilawati N. Relationship of knowledge and support of family members with the preparedness of households in the face of earthquake disaster in Hamlet Soronanggan Panjangrejo Pundong Bantul [thesis]. Yogyakarta: STIKES ' Aisyiyah Yogyakarta; 2015.

[9] LIPI-UNESCO/ISDR. Research on community preparedness in anticipating earthquake and Tsunami disasters. 2006.

[10] Ahmad. SL. Analysis of factors related to family preparedness in the face of disaster impact in Ternate, North Maluku Province [thesis]. Malang: Universitas Brawijaya; 2017.

[11] Havwina T, Maryani E, Nandi. The influence of disaster experience on the preparedness of learners in the face of earthquake and Tsunami threat. Geography of Education Journal. 2016; 16 (2): 124-31.

[12] Permana RA. Personal experience relationship with flood disaster preparedness in high school students $\mathrm{Al}$ Hasan Village Kemiri Subdistrict Orphanage [thesis]. Jember: University of Jember; 2015.

[13] Fitriana L, Suroto, Kurniawan B. Factors related to the efforts of preparedness of employees ' production in the face of fire hazard in PT Sandang Asia Maju Abadi. Public Health Journal. 2017; 5 (3): 295-307.

[14] Wahidah DA, Rondhianto, Hakam M. Factors influencing nurse preparedness in the face of flood disaster in Gumukmas subdistrict, Jember district. Health library e-journals. 2016; 4 (3): 568-7 